\title{
ANALYSIS OF PROFITABILITY OF RAW MILK PRODUCTION IN A COMMERCIAL FARM BEFORE AND AFTER POLAND'S ACCESSION TO THE EU
}

\section{ANALIZA OPŁACALNOŚCI PRODUKCJI MLEKA SUROWEGO W GOSPODARSTWIE WIELKOTOWAROWYM, Z UWZGLĘDNIENIEM OKRESU PRZED I PO PRZYSTĄPIENIU POLSKI DO UNII EUROPEJSKIEJ}

\author{
Department of Animal Breeding and Product Quality Assessment, Poznań University of Life Sciences, \\ Poland \\ ${ }^{1}$ Computer Lab, Poznań University of Life Sciences, Poland \\ 2Department of Ruminant Science, West Pomeranian University of Technology, Szczecin, Poland
}

\begin{abstract}
Streszczenie. Celem opracowania było przeprowadzenie analizy opłacalności produkcji mleka w gospodarstwie typu farmerskiego w dwóch okresach - pierwszym przed przystąpieniem Polski do UE (od 1998 do kwietnia 2004 r.) i drugim po przystąpieniu (od maja 2004 do 2012 r.). Uzyskane dane umożliwiły wyliczenie średnich rocznych wartości z następujących pozycji w kalkulacji: stanu krów, produkcji mleka sprzedanego, produkcji mleka paszowego, ceny zbytu mleka, odchowu cieląt, sprzedaży żywca wołowego, sprzedaży krów wybrakowanych, łącznych przychodów z produkcji mleka, kosztów bezpośrednich, kosztów pasz, kosztów obsługi, kosztów pośrednich z amortyzacją, łącznych kosztów produkcji mleka, kosztów bezpośrednich produkcji 1 I mleka, kosztów całkowitych produkcji 1 I mleka, zysku/straty z produkcji bydła, zysku/straty z produkcji 1 I mleka, wartości produkcji przypadającej na 1 krowę, zysków/straty z produkcji mleka przypadającej na jedną krowę, relacji ceny zbytu mleka do kosztów produkcji oraz wskaźnika opłacalności produkcji mleka. W badaniach dokonano także zestawienia: zysków / strat z produkcji 1 I mleka oraz wskaźników opłacalności produkcji w analizowanych latach. Wykazano, że po przystąpieniu Polski do Unii Europejskiej w analizowanym gospodarstwie pod względem statystycznym wysokoistotnie zmieniły się przychody i koszty związane z produkcją mleka surowego. Wartości tych parametrów wzrosły w odniesieniu do okresu wcześniejszego. Odnotowano wzrost produkcji mleka oraz zysku przypadającego na jedną krowę, co najprawdopodobniej było skutkiem realizowanej pracy hodowlanej i uzyskiwanego postępu genetycznego oraz produkcyjnego w stadzie. Jednakże porównując okres przed przystąpieniem Polski do UE i po nim nie odnotowano różnicy statystycznie istotnej w przypadku zysku/straty przypadającej na produkcję 1 I mleka oraz wskaźnika opłacalności produkcji mleka. Okres po przystąpieniu Polski do UE, w relacji do okresu poprzedzającego, charakteryzował się bardziej dynamicznymi zmianami wskaźników opłacalności produkcji mleka surowego, co wpłynęło na mniejszą stabilność poziomu rentowności tej gałęzi produkcji zwierzęcej.
\end{abstract}

Key words: economics of milk production, income from milk production, milk production costs, milk production profitability index.

Słowa kluczowe: ekonomika produkcji mleka, przychody z produkcji mleka, koszty produkcji mleka wskaźnik opłacalności produkcji mleka.

Corresponding author - Adres do korespondencji: Ireneusz R. Antkowiak, Department of Animal Breeding and Product Quality Assessment, Poznań University of Life Sciences, Słoneczna 1, Złotniki, 62-002 Suchy Las, Poland, e-mail: irekantk@up.poznan.pl 


\section{INTRODUCTION}

In order to be competitive farms specialising in commercial milk production need to constantly strive to reduce their financial outlays related to milk production, while at the same time increasing their income from this branch of animal production. In the opinion of Otoliński and Szarek (2002), apart from the law of supply and demand the value of a product on the market depends also on inflation and it may be regulated using state interventionism policy by the implementation of the price floor, intervention buying and production subsidies. Implementation of such tools typically results from the situation in the global milk market, which is beyond the control of producers. Producers need to focus on the reduction of incurred costs connected with milk production on their farms to ensure the highest possible added value for the production of $1 \mathrm{~kg}$ milk. According to Ziętara (2001), outlays on milk production may be divided into fixed and variable costs. The former group of costs includes expenses related with the purchase and production of feeds, Al and veterinary services, labour, livestock insurance, etc. The latter group of costs comprises costs of fuel, electricity, repair and maintenance of facilities, machines and equipment, insurance of buildings and movable tangible assets, property insurance, national farmers' insurance contributions [KRUS], taxes, lease and rent, interest on loans as well as general labour costs.

Despite concerns and controversies among Polish milk producers, Poland's accession to the EU in May 2004 has brought numerous benefits. For the dairy industry it has opened new channels for trade with other EU countries with no duties or non-tariff barriers. Following Poland's accession to the EU export of dairy products (expressed in EUR) increased by approx. 70\% in comparison to the figures from 2003 (Sołacki 2014). Currently Poland ranks fourth in the EU after Germany, France and Great Britain and it generates $8.3 \%$ milk production in the EU. i.e. 12447 thousand ton (Olszewska 2015). At Poland's accession to the EU Polish agriculture was incorporated into the CAP framework. The system of milk quotas was introduced in the EU countries in 1984 to solve the problem of surplus dairy products on the market. Poland implemented milk production quotas on 1 April, 2004. Reduction of milk production has contributed to the stabilisation of the dairy sector. However, the system of milk quotas was binding in all EU countries until April, 2015. The aim of lifting production quotas is to strengthen EU competitiveness on the global markets.

An issue of interest both for milk producers and processors is related with the modification of raw milk production profitability in a commercial farm in the period before and after Poland's accession to the EU. For this reason the aim of this study was to analyse milk production profitability over a period of more than a decade in a large commercial farm by comparing the period before and after Poland's accession to the EU.

\section{MATERIAL AND METHODS}

Data concerning income and incurred costs connected with milk production in the years 1998-2012 were collected from the financial and accounting documents of the Ciążen farm belonging to Gospodarstwo Rolno-Przemysłowe „Rolgos” Sp. z o.o. in Paruszewo. Obtained data were divided in terms of two periods, one before Poland's accession to the EU structures, covering the period from 1998 to April 2004, and the other following accession, i.e. from May 
2004 to 2012 . The aim of this study was realised also using information from breeding records and concerning cattle performance. Based on this body of source data mean annual values were calculated for the following items in the calculations: the number of cows, sold milk production, production of milk to be fed, milk sales price, calf rearing, sales of cattle for slaughter, sale of culled cows, total income from milk production, direct costs, costs of feeds, handling costs, indirect costs including depreciation, total costs of milk production, direct production costs per $1 \mathrm{I}$ milk, total production costs per $1 \mathrm{I}$ milk, profit/loss from cattle production, profit/loss from production of 1 I milk, production value per $1 \mathrm{cow}$, profit/loss from milk production per $1 \mathrm{cow}$, the ratio of milk sales price to production costs and milk production profitability index. The following income from milk production: sold milk and fed milk, value of calf rearing, value of cattle for slaughter and value of culled cows were taken into account for the calculation of profit of milk. Direct costs in milk production included outlays on concentrates, purchased feeds, fodder, veterinary services and medication, Al services and bull semen costs, cleaning supplies and chemicals used in milk production and collection, wages and energy. In turn, indirect costs included outlays on rent, administrative costs and interest on loans. In this study milk production profitability on a commercial farm was compared in terms of two periods: one prior to Poland's accession to the EU (from 1998 to April, 2004) and the other following the accession (from May, 2004 to 2012). This study comprises also figures for profit/loss per $1 \mathrm{I}$ produced milk as well as milk production profitability indexes for the successive years in the period of 1998-2012. The profit of milk was calculated by subtracting from total income total cost of milk production (direct and indirect costs). The production profitability index has been calculated by dividing the total value of income and of the total costs of milk production.

Statistical analyses were performed using the SAS package (2015). The MEANS procedure was applied. Significance of the effect of experimental factor (period) was determined using single factorial analysis of variance with the GLM procedure based on the following linear model:

$$
Y_{i j}=\mu+o_{i}+e_{i j}
$$

where:

$y_{i j}$ - phenotypic value of analysed trait;

$\mu$ - population mean;

$o_{i}-$ fixed effect of $i$-th period $(I=1,2)$;

$e_{i j}-$ random error.

In order to provide specific comparisons of object means a series of multiple comparisons was performed using the student's t-test.

\section{RESULTS}

Table 1 presents revenue and costs of milk production for a farm in Ciążeń in the periods before and after Poland's accession to the European Union. Statistical analysis showed that the period of analysis had a significant effect $(P \leq 0.01)$ on values of investigated parameters. 
Table 1. Income and costs of milk production on the dairy cattle farm in 1998-2012, divided into periods before and after accession to the EU

Tabela 1. Przychody i koszty produkcji mleka na fermie krów mlecznych w latach 1998-2012, z podziałem na okres przed przystąpieniem do Unii Europejskiej i po nim

\begin{tabular}{|c|c|c|c|c|c|c|c|}
\hline \multirow[t]{2}{*}{$\begin{array}{c}\text { Specification } \\
\text { Wyszczególnienie }\end{array}$} & \multirow{2}{*}{$\begin{array}{l}\text { Significance } \\
\text { of effect } \\
\text { Istotność } \\
\text { wpływu }\end{array}$} & \multicolumn{3}{|c|}{$\begin{array}{l}\text { Before accession to the EU } \\
\text { Przed wstapieniem do Unii } \\
\text { Europejskiej }\end{array}$} & \multicolumn{3}{|c|}{$\begin{array}{c}\text { After accession to the EU } \\
\text { Po wstapieniu do Unii } \\
\text { Europejskiej }\end{array}$} \\
\hline & & $\bar{x}$ & & CV & $\bar{x}$ & & $\mathrm{CV}$ \\
\hline $\begin{array}{l}\text { Mean annual number of cows } \\
\text { Średni roczny stan krów }\end{array}$ & ** & 85.80 & A & 12.85 & 126.63 & B & 25.35 \\
\hline \multirow{3}{*}{$\begin{array}{l}\text { Milk production including: } \\
\text { Produkcja mleka [l], w tym: } \\
\text { sold milk - mleka sprzedanego } \\
\text { milk to be fed - mleka paszowego }\end{array}$} & ** & 48321.51 & A & 9.05 & 76115.51 & B & 27.51 \\
\hline & ** & 45412.26 & $A$ & 4.35 & 74718.41 & $B$ & 27.58 \\
\hline & ** & 2909.25 & $\mathrm{~A}$ & 129.91 & 1397.10 & $\mathrm{~B}$ & 43.68 \\
\hline $\begin{array}{l}\text { Sales price of } 1 \text { I milk } \\
\text { Cena zbytu } 1 \text { I mleka [PLN] }\end{array}$ & ** & 0.88 & A & 8.15 & 1.13 & $\mathrm{~B}$ & 10.81 \\
\hline $\begin{array}{l}\text { Sold milk } \\
\text { Mleko sprzedane [PLN] }\end{array}$ & $* *$ & 40663.75 & A & 17.52 & 86207.56 & $\mathrm{~B}$ & 34.83 \\
\hline $\begin{array}{l}\text { Milk to be fed } \\
\text { Mleko paszowe [PLN] }\end{array}$ & ** & 1250.63 & A & 117.21 & 799.02 & B & 45.65 \\
\hline $\begin{array}{l}\text { Calf rearing } \\
\text { Odchów cieląt [PLN] }\end{array}$ & ** & 2362.50 & $A$ & 40.99 & 4613.06 & B & 56.69 \\
\hline $\begin{array}{l}\text { Cattle for slaughter } \\
\text { Żywiec bydlęcy [PLN] }\end{array}$ & * & 2458.35 & a & 95.87 & 3810.00 & $\mathrm{~b}$ & 125.79 \\
\hline $\begin{array}{l}\text { Value of culled cows } \\
\text { Wartość wybrakowanych krów } \\
\text { [PLN] }\end{array}$ & - & $\begin{array}{l}\text { no information } \\
\text { brak danych }\end{array}$ & & - & 4788.29 & & 100.11 \\
\hline $\begin{array}{l}\text { Total income } \\
\text { Łączna wartość przychodów [PLN] }\end{array}$ & $* *$ & 46379.41 & $A$ & 15.20 & 95202.39 & B & 35.05 \\
\hline \multirow{4}{*}{$\begin{array}{l}\text { Total direct costs including: } \\
\text { Koszty bezpośrednie [PLN], w tym: } \\
\text { feeds - pasz } \\
\text { farm fodders - pasz własnych } \\
\text { purchased fodders } \\
\text { pasz zakupionych }\end{array}$} & ** & 29092.57 & A & 16.47 & 63117.40 & B & 44.96 \\
\hline & ** & 15354.87 & $\mathrm{~A}$ & 21.41 & 35160.97 & $\mathrm{~B}$ & 54.64 \\
\hline & ** & 11067.25 & $\mathrm{~A}$ & 25.09 & 19638.33 & $B$ & 47.93 \\
\hline & $* *$ & 4287.62 & $A$ & 44.28 & 15522.64 & B & 66.29 \\
\hline $\begin{array}{l}\text { Handling costs } \\
\text { Koszty obsługi }[\mathrm{PLN}]\end{array}$ & ** & 13737.70 & A & 20.33 & 28016.44 & B & 35.89 \\
\hline $\begin{array}{l}\text { Indirect costs with depreciation } \\
\text { Koszty pośrednie związane } \\
\text { z amortyzacją [PLN] }\end{array}$ & ** & 3491.11 & $A$ & 16.47 & 8479.93 & B & 55.11 \\
\hline $\begin{array}{l}\text { Total milk production cost } \\
\text { Łączny koszt produkcji mleka } \\
{[\text { PLN] }}\end{array}$ & $* *$ & 32583.67 & $A$ & 16.43 & 71657.33 & B & 46.07 \\
\hline $\begin{array}{l}\text { Direct production cost per } 1 \text { I milk } \\
\text { Koszt bezpośredni produkcji } \\
1 \text { I mleka [PLN] }\end{array}$ & $* *$ & 0.60 & $A$ & 13.56 & 0.80 & $B$ & 24.47 \\
\hline $\begin{array}{l}\text { Total production cost of } 1 \text { I milk } \\
\text { Koszt całkowity produkcji } \\
1 \mathrm{~kg} \text { mleka [PLN] }\end{array}$ & $* *$ & 0.67 & $A$ & 13.57 & 0.90 & $B$ & 25.69 \\
\hline
\end{tabular}

**highly significant - statystycznie wysokoistotny $(P \leq 0.01)$; ${ }^{*}$ significant - statystycznie istotny $(P \leq 0.05)$; NS non-significant - statystycznie nieistotny $(P>0.05)$.

Means denoted with different letters (in rows) differ statistically - Średnie oznaczone odmiennymi literami ( $w$ wierszach) różnią się: $A B-(P \leq 0.01) ; a b-(P \leq 0.05)$.

Only for income generated by sale of cattle for slaughter the means differed at the significance level $P \leq 0.05$. For all the analysed parameters (except for the value of production of milk to be fed and its sales price) greater values were recorded for the period following Poland's accession to the EU in relation to the period prior to accession. It may be stated that in the post-accession period the average sales price for $1 \mathrm{I}$ milk increased considerably (by 0.25 PLN), while the total income from milk production was two-fold greater in comparison to the pre-accession period. Total milk production costs in the period from May, 2004 to 2012 were 2.2 times greater than before the accession. Particularly high increases were recorded for 
outlays on feed purchase (3.6-fold) and indirect costs including depreciation (2.4-fold). The total production cost per $1 \mathrm{I}$ milk in the periods before and after Poland's accession to the EU amounted to 0.67 PLN and 0.90 PLN, respectively.

Table 2 presents milk production profitability indexes in the two analysed periods. It was shown that the period of analysis had a significant effect $(P \leq 0.01)$ on profit/loss from cattle production and the value of production per 1 cow. In the case of profit/loss per 1 cow this dependence was observed at the significance level $P \leq 0.05$. Values of these indexes were higher in the post-accession period. No statistical differences were found between the two analysed periods in terms of the ratio of sales price to costs of milk production and the production profitability index.

Table 2. Profitability indexes for milk production on the dairy cattle farm in 1998-2012, divided into periods before and after accession to the EU

Tabela 2. Wskaźniki opłacalności produkcji mleka na fermie krów mlecznych w latach 1998-2012, z podziałem na okres przed przystąpieniem do Unii Europejskiej i po nim

\begin{tabular}{|c|c|c|c|c|c|c|c|}
\hline \multirow[t]{2}{*}{$\begin{array}{c}\text { Specification } \\
\text { Wyszczególnienie }\end{array}$} & \multirow[t]{2}{*}{$\begin{array}{l}\text { Significance } \\
\text { of effect } \\
\text { Istotność } \\
\text { wpływu }\end{array}$} & \multicolumn{3}{|c|}{$\begin{array}{c}\text { Before accession to the EU } \\
\text { Przed przystąpieniem } \\
\text { do Unii Europejskiej }\end{array}$} & \multicolumn{3}{|c|}{$\begin{array}{c}\text { After accession to the EU } \\
\text { Po przystąpieniu do Unii } \\
\text { Europejskiej }\end{array}$} \\
\hline & & $\bar{x}$ & & CV & $\bar{x}$ & & $\mathrm{CV}$ \\
\hline $\begin{array}{l}\text { Profit / loss from cattle production } \\
\text { Zysk / strata z produkcji bydła } \\
\text { [PLN] }\end{array}$ & $* *$ & 13795.74 & A & 28.60 & 23545.06 & B & 46.17 \\
\hline $\begin{array}{l}\text { Profit / loss per } 1 \text { I of milk } \\
\text { Zysk / strata na } 1 \text { I mleka } \\
\text { [PLN] }\end{array}$ & NS & 0.21 & & 32.71 & 0.23 & & 66.52 \\
\hline $\begin{array}{l}\text { Value of production per cow } \\
\text { Wartość produkcji na krowę } \\
\text { [PLN] }\end{array}$ & $* *$ & 554.49 & A & 27.69 & 737.37 & B & 14.71 \\
\hline $\begin{array}{l}\text { Profit / loss per cow } \\
\text { Zysk / strata na krowę } \\
{[\text { PLN] }}\end{array}$ & * & 166.21 & a & 40.89 & 195.27 & $\mathrm{~b}$ & 44.41 \\
\hline $\begin{array}{l}\text { Ratio of milk sale price to milk } \\
\text { production costs } \\
\text { Stosunek ceny zbytu do kosztów } \\
\text { produkcji mleka }\end{array}$ & NS & 1.33 & & 10.21 & 1.31 & & 16.89 \\
\hline $\begin{array}{l}\text { Production profitability index } \\
\text { Wskaźnik opłacalności produkcji } \\
\text { mleka [\%] }\end{array}$ & NS & 132.59 & & 10.21 & 130.50 & & 16.89 \\
\hline
\end{tabular}

Explanations see Table 1 - Objaśnienia zob. tab. 1.

Figure 1 presents a curve with the quadratic polynomial trend concerning profits/losses per $1 \mathrm{I}$ milk in individual years in the investigated periods. Values of this parameter were highest (0.36 PLN) and lowest (0.07 PLN) during one period, following Poland's accession to the EU, in the year 2005 and in the years 2011-2012. Values of this index below the established trend in the pre-accession period from 2000 to the end of March, 2004, while in the post-accession period such a trend was observed only in the years 2011-2012. In the period prior to Poland's accession to the EU the lowest profit from the production of 1 I milk was observed in 2000 (0.17 PLN), while it was highest (0.24 PLN) in 1999. Similar directions of changes in individual years were found for the milk production profitability index (Fig. 2). The greatest milk production profitability (153.0\%) was recorded in 2005, while it was lowest in 2012 and 2011, amounting to $106.3 \%$ and $106.4 \%$, respectively. No analogously marked changes in the values of this index were observed in individual years prior to Poland's accession to the EU. The difference between the highest (1998) and the lowest value (2000) of the milk production profitability index was $16.4 \%$. 


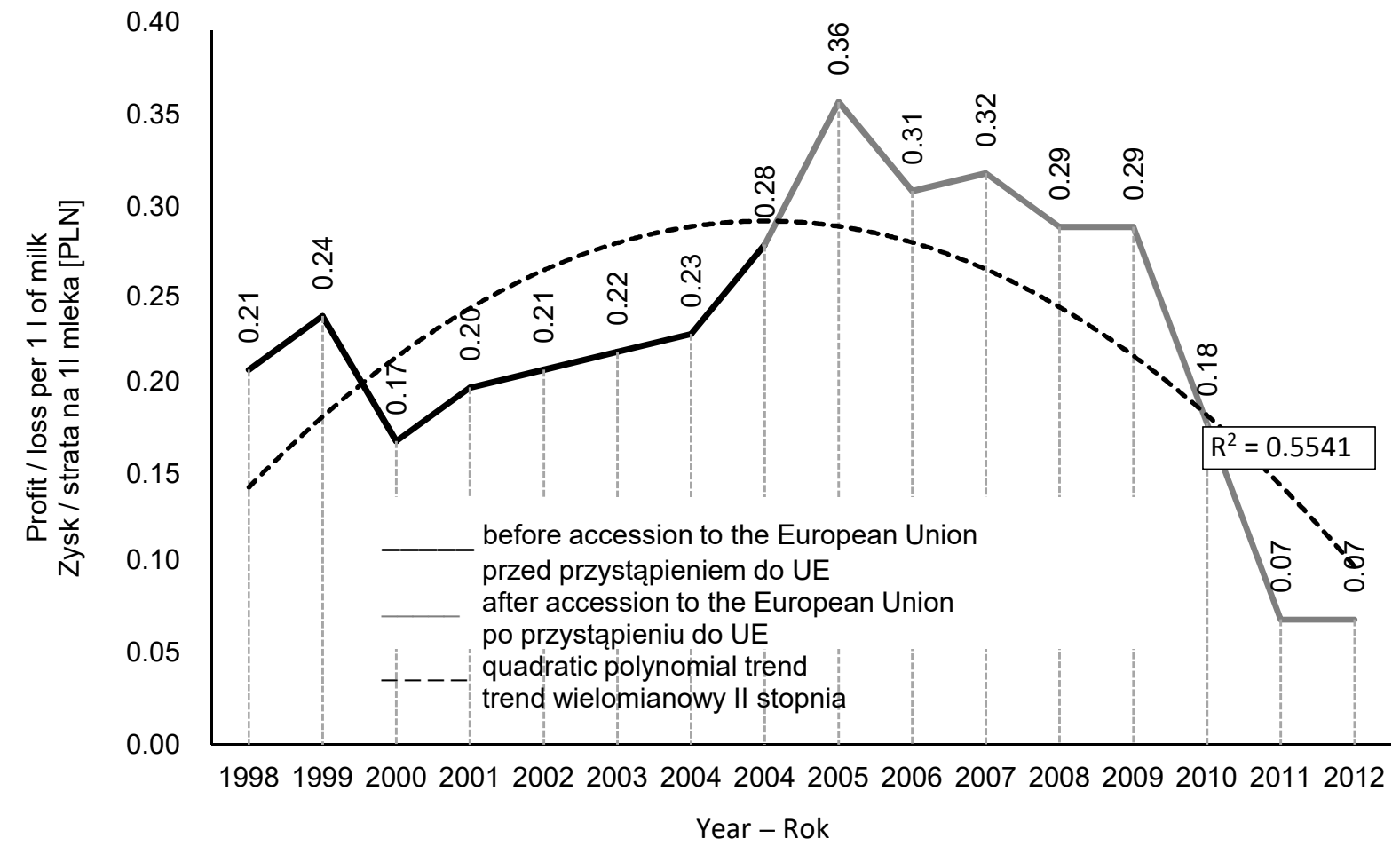

Fig. 1. Profit / loss per $1 \mathrm{I}$ of milk on the dairy cattle farm in analysed years with a quadratic polynomial trend Ryc. 1. Zyski / straty przypadające na 1 I mleka na fermie krów mlecznych w analizowanych latach, $\mathrm{z}$ trendem wielomianowym II stopnia

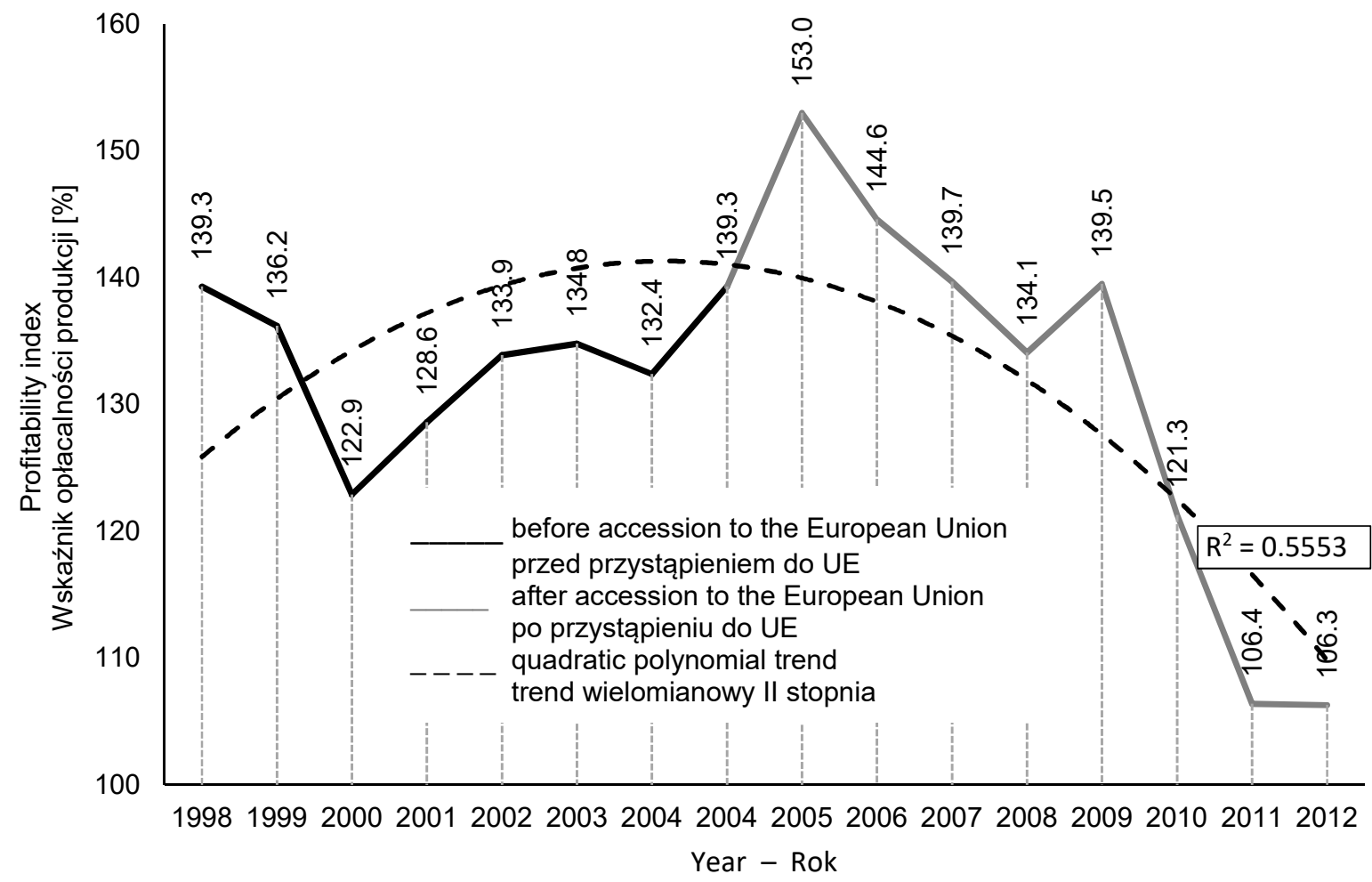

Fig. 2. Profitability indexes for milk production on the dairy cattle farm in analysed years with a quadratic polynomial trend

Ryc. 2. Wskaźniki opłacalności produkcji mleka na fermie krów mlecznych w analizowanych latach, $\mathrm{z}$ trendem wielomianowym II stopnia 


\section{DISCUSSION}

Milk production profitability is influenced primarily by herd size, type of production, unit yield and milk purchase price (Sznajder 1999). In turn, Okularczyk (2001) was of an opinion that factors to the greatest extent modifying profits from cattle rearing include quality of produced milk and the origin of feeds used. In this study after Poland's accession to the EU in relation to the pre-accession period on that farm the average annual number of cows increased by $48 \%$, while milk production increased by approx. $65 \%$, which most probably considerably affected the economic aspect of milk production. It is assumed that milk production costs in large herds are lower than in small ones (Hadley et al. 2002; Wolf 2003). Typically a decrease in the number of milk producers is connected with increased concentration of production, accompanied by the growing herd size and enhanced milk yields of cows (Wilson 2011). According to Chabuza (2013), in the case of international cattle breeds the primary factors affecting profitability include the scale of milk production and its cost, while in the case of local breeds income was determined by the maximum utilisation of EU subsidies. Maximised milk production makes it possible to reduce the number of kept cows and thus to lower feed consumption needed to cover maintenance requirements in relation to production requirements, while it also results in lower outlays connected with depreciation of stalls and labour costs (Okularczyk 2004a).

It was shown when analysing Czech farms that herds with the highest average milk yields generated the highest net profit from milk production despite greater problems with fertility (Krpálková et al. 2014). Ziętara (2007) suggested that costs of feeds, Al and veterinary services as well as outlays on the maintenance of animal housing facilities are higher on farms keeping herds of high-yielding cows. Moreover, the period of productive life is typically shorter in the case of high-yielding cows, while depreciations costs connected with herd replacement should amount to approx. 12\% average value of produced milk (Krencik and Łukaszewicz 1990).

In the opinion of Honarvar et al. (2010), longevity is an important economic trait in dairy cattle and it needs to be considered in breeding programmes. According to Heikkilä et al. (2008), in order to improve economic results of milk production very early culling needs to be limited and in the long term it is recommended to focus on the state of health and longevity of cows and on their milking performance. When improving milk yields of cows it should be stressed that each successive $\mathrm{kg}$ of produced milk causes an increase in feed consumption, particularly concentrates, which are the most expensive feeds. Okularczyk (2004b) showed that the primary factor in profitability of cow rearing is their productivity and the proportion of fodder produced on the farm in their feeding. In a study conducted in the Czech Republic by Krpálková et al. (2017) it was found that herds producing on average $\geq 9000 \mathrm{~kg}$ milk were characterised by the lowest milk production costs, amounting to 0.32 EUR/I.

According to Mańko (2005), farmers having herds of high-producing cows more often purchase concentrates, which as a rule is connected with insufficient acreage for cereal growing, since a considerable share of arable land in those farms is allocated to the production of fodder. In turn, fodder production on permanent grassland is cheaper than on arable land (Kordecki and Szarek 2011). 
When analysing outlays on feeds in the investigated farm it was found that in the post-accession period outlays on purchased feeds increased considerably (by $262 \%$ ) in comparison to the increase (by $78 \%$ ) of costs incurred on fodder produced on the farm. Considering the total production cost of $1 \mathrm{I}$ milk and the sales price of milk it was shown that in the post-accession period they were higher by 0.23 PLN and 0.25 PLN, respectively, in comparison to those in the pre-accession period. In turn, profit from the production of 1 I milk was comparable, amounting in the pre-accession period to $0.21 \mathrm{PLN}$ and to $0.23 \mathrm{PLN}$ in the post-accession period.

The greatest profit $(0.36 \mathrm{PLN})$ from 1 I produced milk was recorded in 2005 . Higher values of that index were reported by Pytlewski et al. (2014) when analysing profitability of milk production in the period from 2001 to 2012 in a herd with an average of 100 cows. Those authors showed that the lowest profit from 1 I produced milk amounted to 0.31 PLN (in 2003), while it was highest at 0.59 PLN (in the period from September to December 2007). In turn, in 2005 the profit from 1 I milk in the analysed cooperative farm was 0.49 PLN. A similar value (0.45 PLN) for that index was obtained for the year 2005 by Nowakowska (2007), when investigating a herd of approx. 270 cows. Considering milk production profitability that author for the years 2003-2006 and Pytlewski et al. (2014) for the years 2001-2012 obtained much higher values of that index. Sobczyński et al. (2015) when analysing milk production efficiency on farms in two Polish provinces: the Wielkopolskie and the Podlaskie, found that farms in those regions are capable of competing with farms of four countries being the largest milk producers in the EU. This is because of the potential for improvement of the average milk yield per cow in those two Polish provinces and thanks to the potential to reduce milk production costs. In another study Sobczyński et al. (2013) reported that in every region of Poland there are many farms which may improve cost-effectiveness of milk production in order to increase their competitiveness.

Obtained results indicate that Poland's accession to the EU brought about a certain improvement in milk production profitability in the analysed farm, although a greater variation was observed in values of milk production profitability indexes in individual years of the post-accession period. This shows greater fluctuations in production profitability of raw milk in the post-accession period.

\section{CONCLUSIONS}

1. It was shown that after Poland's accession to the EU in the analysed farm income and costs connected with the production of raw milk were changing statistically highly significantly. Values of these parameters increased in comparison to the pre-accession period.

2. Following Poland's accession to the EU milk production and profit per $1 \mathrm{cow}$ increased, which was most probably connected with the conducted breeding work and gained genetic progress and increased productivity in the evaluated herd. However, when comparing the period before and after Poland's accession to the EU no statistically significant differences were observed for profit/loss per 1 I produced milk and the milk production profitability index.

3. The post-accession period in comparison to the pre-accession period showed more dynamic changes in profitability indexes for raw milk production, which resulted in a lesser stability of profitability in this branch of animal production. 


\section{REFERENCES}

Chabuz W. 2013. Efektywnosć chowu bydła i produkcji mleka w gospodarstwach utrzymujących rasy lokalne i wysokoprodukcyjne $z$ uwzględnieniem systemu utrzymania [The efficiency of cattle breeding and milk production on farms, keeping local and highly productive breeds with consideration of the system employed]. Rocz. Nauk. PTZ 9(2), 9-21. [in Polish]

Hadley G.L., Harsh S.B., Wolf C.A. 2002. Managerial and financial implications of major dairy farm expansions in Michigan and Wisconsin. J. Dairy Sci. 85, 2053-2064.

Heikkilä A.M., Nousiainen J.I., Jauhiainen L. 2008. Optimal replacement policy and economic value of dairy cows with diverse health status and production capacity. J. Dairy Sci. 91, 2342-2352.

Honarvar M., Javaremi A.N., Ashtiani S.R.M., Banadaki M.D. 2010. Effect of lenght of productive life on genetic trend of milk production and profitability: A simulation study. African J. Biotech. 9, 3000-3010.

Kordecki S., Szarek J. 2011. Systemy karmienia [Feeding systems]. Hoduj z Głową 5-6, 74-77. [in Polish]

Krencik D., Kukaszewicz M. 1990. Długowieczność krów jeszcze jeden element selekcji [Longevity of cows is yet another element of selection]. Prz. Hod. 4, 12-17. [in Polish]

Krpálková L., Cabrera V.E., Kvapilík J., Burdych J., Crump P. 2014. Associations between age at first calving, rearing, average daily weight gain, herd milk yield and dairy herd production, reproduction and profitability. J. Dairy Sci. 97, 6573-6582.

Krpálková L., Syrůček J., Kvapilík J., Burdych J. 2017. Analysis of milk production, age at first calving, calving interval and economic parameters in dairy cattle management. Mljekarstvo 67, 58-70.

Mańko S. 2005. Sytuacja ekonomiczna i koszty produkcji w gospodarstwach nastawionych na produkcję mleka. Cz. II. [Economic situation and production costs in farms oriented to milk production. Part II]. Prz. Mlecz. 10, 28-30. [in Polish]

Nowakowska M. 2007. Ekonomika produkcji mleka krów rasy jersey i polskiej holsztyńsko-fryzyjskiej odmiany czarno-białej. Poznań, AR (typescript). [in Polish]

Okularczyk S. 2001. Jakość mleka i czynniki rynkowe w opłacalności jego produkcji [Quality of milk and market factors in the profitability of its production]. Zesz. Nauk. Prz. Hod. 55, 113-121. [in Polish]

Okularczyk S. 2004a. Opłacalność produkcji mleka krowiego w latach 1991-2003 [Profitability of cow milk production in 1991-2003]. Wieś Jutra 11/12, 17. [in Polish]

Okularczyk S. 2004b. Opłacalność produkcji mleka krowiego w latach 1991-2003. [Profitability of cow milk production in 1991-2003]. Rocz. Nauk. Stow. Ekon. Rol. Agrobiz. 6, 158-163. [in Polish]

Olszewska M. 2015. Produkcja mleka w Polsce na tle świata i krajów Unii europejskiej [Milk production in Poland against the world and European Union countries]. Wiad. Zoot. 150-156. [in Polish]

Otoliński S., Szarek J. 2002. Ekonomika produkcji mleka [The economics of milk production]. Prz. Hod. 5, 16-20. [in Polish]

Pytlewski J., Antkowiak I., Idkowiak K., Skrzypek R. 2014. Analiza opłacalności produkcji mleka w latach 2001-2012 na przykładzie RSP „Przyszłość” z uwzględnieniem zmiany systemu utrzymania krów [Analysis of profitability of milk production in 2001-2012 based on the „Przyszłość” farming cooperative in terms of changes in cow housing system]. Nauka Przyr. Technol. 8(1), 3. [in Polish]

SAS ${ }^{\circledR}$ user's guide. Statistics version 9.4 edition. 2015. Cary, NC, SAS Institute.

Sobczyński T., Klepacka A.M., Revoredo-Giha C., Florkowski W.J. 2013. The analysis of subregional differences in cost efficiency of polish dairy farms using the FADN datebase. Rocz. Nauk. Ekon. Rol. Rozw. Obsz. Wiej. 100, 103-113.

Sobczyński T., Klepacka A.M., Revoredo-Giha C., Florkowski W.J. 2015. Dairy farm cost efficiency in leading milk-producing regions in Poland. J. Dairy Sci. 98, 8294-8307.

Sołacki K. 2014. Wpływ wejścia Polski do Unii Europejskiej na handel zagraniczny produktami mleczarskimi [The impact of Polish entry into the European Union's foreign trade in dairy products]. Prz. Mlecz. 3, 14. [in Polish] 
Sznajder M. 1999. Ekonomika mleczarstwa. Poznań, Wydaw. AR. [in Polish]

Wilson P. 2011. Decomposing variation in dairy profitability: the impact of output, input, prices, labour and management. J. Agri. Sci. 149, 507-517.

Wolf C.A. 2003. The economics of dairy production. Vet. Clin. North Am. Food Anim. Pract. 19, 271-293.

Ziętara W. 2001. Ekonomiczne aspekty produkcji mleka w gospodarstwach rolniczych [Economic aspects of milk production in farms]. Prz. Hod. 5, 9-13. [in Polish]

Ziętara W. 2007. Stan i kierunki rozwoju gospodarstw nastawionych na produkcję mleka [State and directions of the development of farms focused on milk production]. Prz. Hod. 5, 3-6. [in Polish]

Abstract. The aim of this study was to analyse milk production profitability over a period of more than a decade in a commercial farm in terms of two periods: prior to Poland's accession to the EU (from 1998 to April, 2004) and after accession (from May, 2004 to 2012). Obtained source data made it possible to calculate mean annual values for the following items in these calculations: the number of cows, production of milk sold, production of milk to be fed, milk sales price, calf rearing, sales of slaughter cattle, sales of culled cows, total income from milk production, direct costs, feed costs, handling costs, indirect costs including depreciation, total milk production costs, direct costs per 1 I produced milk, total costs per 1 I produced milk, profit/loss from cattle production, profit/loss from 1 I produced milk, value of production per $1 \mathrm{cow}$, profit/loss from milk production per $1 \mathrm{cow}$, the ratio of milk sales price to production costs and profitability index for milk production. Within this study data were also collected on profit/loss per 1 I produced milk and milk production profitability indexes in the analysed years. It was shown that following Poland's accession to the EU in the analysed farm statistically highly significant changes were observed in income and costs connected with the production of raw milk. Values of these parameters increased in comparison to the previous period. An increase was recorded in milk production and profit per $1 \mathrm{cow}$, which was most probably a consequence of breeding work and gained genetic progress and increased productivity in the herd. However, when comparing the period before and after Poland's accession no statistically significant differences were found for profit/loss per 1 I produced milk and milk production profitability indexes. The post-accession period in relation to the previous period was characterised by more dynamic changes in profitability indexes for raw milk production, which resulted in a lesser stability in profitability for this branch of animal production. 